\title{
技術論文
}

\author{
$\mathrm{KSR}-\mathrm{III}$ 로켓엔진의 연소 안정성 평가 \\ 손채훈*, 김영목**
}

\section{Stability Rating of KSR-III Rocket Engine}

Chae-Hoon Sohn* and Young-Mog Kim**

\begin{abstract}
Stability rating of KSR-III rocket engine is conducted based on stability rating tests in the course of development of KSR-III rocket engine. Rocket engine is approved to have combustion stabilization ability when it can suppress the external perturbation or pressure oscillation with finite amplitude and recover the original stable combustion. Rocket engine in flight may be perturbed by unexpectedly large-amplitude pressure oscillation and thus a designer should not only assure combustion stabilization ability of the engine but also quantify the stabilization capacity. For this, principal quantitative parameters and their evaluation are introduced. To verify dynamic stability of KSR-III rocket engine, six stability rating tests have been conducted. Based on these test results, such parameters are quantified and thereby, the stabilization capacity of KSR-III rocket engine is evaluated.
\end{abstract}

\section{초 록}

액체 로켓엔진 개발과정에서 수행되는 여러 가지 시험 중 연소 안정성 평가 시험을 통 해, KSR-III 로켓엔진의 연소 안정성을 평가하였다. 안정성 평가시험에서, 엔진이 외부 교란 에 의한 압력 진동을 감쇠시켜 본래의 안정한 연소를 회복하는 경우, 그 엔진은 연소 안정 화 능력을 가지고 있다고 판정할 수 있다. 로켓엔진은, 교란의 크기를 예측하기 어려운 외 부 섭동에 노출될 수 있으므로, 연소 안정화 가능 여부를 확인하는 것과 더불어 엔진이 갖 고 있는 연소 안정화 성능을 정량화하여 파악하는 작업이 필요하다. 이를 위해 몇 가지 주 요 인자를 도입하였고, 이를 평가하는 방법을 검토하였다. 성공적으로 완료된 KSR-III 로켓 개발과정에서 로켓엔진의 안정성 확보를 위해 6희의 안정성 평가 시험이 수행되었다. 이를 토대로, 연소 안정화 성능의 정량화 방법을 KSR-III 엔진에 적용하여 엔진의 안정화 성능을 분석하였다.

Key Words : Stability Rating (연소 안정성 평가), Combustion Stabilization (연소 안정 화), External Perturbation(외부 교란), Pressure Oscillation(압력 진동), Dynamic Stability (동적 안정성)

\section{I. 서 론}

† 2003년 9월 16일 접수 2004년 2월 18일 심사완료

* 정회원, 조선대학교 항공우주공학과 연락저자, E-mail : chsohn@chosun.ac.kr 광주시 동구 서석동 375

** 정회원, 한국항공우주연구원 추진제어그룹
액체 로켓엔진 개발과정에서 빈번히 발생하는 고주파 연소 불안정(high-frequency combustion instability or acoustic instability)은 과거의 거의 모든 로켓엔진의 개발에 큰 장애요소가 되어왔다 [1]. 고주파 연소 불안정은, 연소 과정 중에 발생 
하는 열방출이, 연소실 내부에서 진동하며 전파 하는 음향파(acoustic wave)와 상호 작용하여 음 향파의 진폭을 어느 한도 이상으로 증폭시키는 현상을 말한다. 따라서, 빈번히 음향 불안정이라 고 불리기도 한다. 이로인해, 분사기면과 연소실 벽면으로의 과도한 열전달 및 그로인한 열손상, 연소실의 극심한 기계적 진동, 불규칙한 추력 변 동 등의 부정적 결과가 초래되는 것으로 알려져 있다 $[2,3]$. 따라서 로켓엔진 개발시 연소실의 음 향 안정성 능력을 확보해야 한다.

로켓엔진이 정상적(normal)으로 작동하더라도 연소실내에는 내재적으로(intrinsically) 항상 어느 정도 크기의 압력 섭동이 존재한다. 통상 연소실 압력의 $\pm 5 \%$ 이내 진폭의 압력 섭동이 존재한다 면 안정한 연소장이라고 할 수 있다[3]. 이를 정 적(static) 안정성이 확보되었다고 말할 수 있다. 그러나, 로켓엔진 연소실은, 동적 시스템으로서 외부에서 상당한 진폭의 교란이 유입될 수 있으 므로, 정적 안정성외에 외부 교란을 감쇠(안정화) 시켜 안정한 연소를 유지할 수 있는 동적 (dynamic) 안정성 여분을 확보하여야 한다.

로켓엔진의 동적 연소 안정성 특성을 아임계 분기 특성으로 이해할 수 있으며, Fig. 1에 도식 적으로 나타내었다. 이 그림에서 가로축은 엔진 의 작동조건을 나타내는 임의의 인자-예를 들 어, 작동압력이나 산화제와 연료의 질량비-이고, 세로축은 엔진 연소실내 압력 섭동의 진폭에 해 당한다. S 형태의 곡선에서 실선부분은 물리적으 로 안정한 상태, 점선은 불안정한 상태를 나타낸 다. 엔진의 작동조건에 따라, (1) 아무리 큰 외부 교란에 의해 초기 정상상태로부터 연소장이 교란 되더라도 본래의 상태로 회복(안정화)되기도 하 며, (2) 특정 크기 이하의 외란에 대해서는 안정 화되나 그 이상의 외란에 대해서는 본래의 정상 상태를 회복하지 못하고 전혀 다른 상태-음향 불안정이 발생한 상태-로 천이되기도 하고, (3) 초기 정상상태 그 자체가 불안정하여 외란이 없 어도 내재적으로 항상 음향 불안정이 발생하는 상태로 천이되기도 한다. 가장 바람직한 경우는 첫 번째의 경우로서, 어떠한 교란에 대해서도 연 소 안정화가 이루어지므로 그러한 엔진은 '절대 적으로 안정'하다고 할 수 있다. 그러나 대부분의 엔진 작동은 두 번째의 상황하에서 이루어지며, 이 경우에 음향 불안정이 야기되지 않는 교란의 최대 진폭을 바로 엔진의 동적 안정성 여분 (margin)이라 할 수 있다.

로켓엔진 개발시 연소 안정성 평가 시험 (stability rating test; SRT)을 수행하는 목적을 크

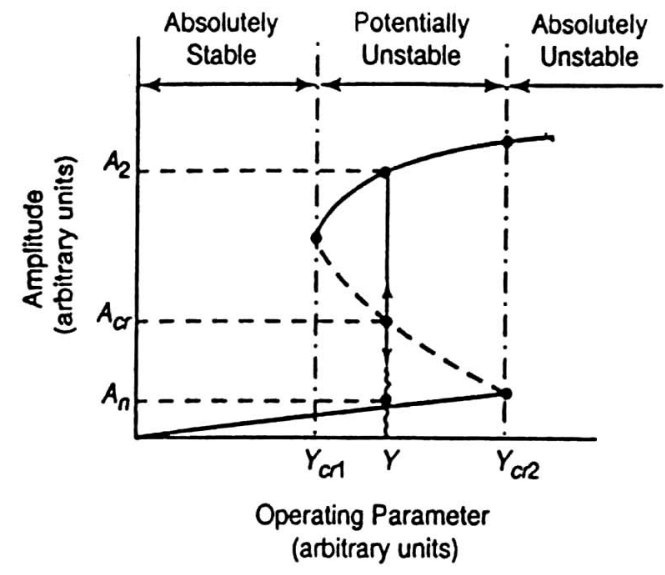

Fig. 1. Pressure fluctuation amplitude in combustion chamber against operating parameter(subcritical bifurcation diagram)[5]

게 두가지로 분류할 수 있다. 한가지는 외부교란 을 감쇠시켜 연소 안정화를 이룰 수 있는지의 여 부를 확인하는 것과 다른 한가지는 동적 안정성 여분과 연소 안정화 성능(capacity)을 평가하는 것이다. 전자는 시험의 결과로서 쉽게 파악될 수 있지만, 후자는 수학적인 분석기술을 필요로 한 다.

본 연구에서는, 연소 안정성을 평가하기 위한 하나의 지침(guide)과 안정화 성능의 정량화에 대 해 고찰하고, 그 결과를 KSR-III 로켓엔진[4]에 적 용하여 엔진의 연소 안정화 성능을 평가하였다.

\section{II. 안정성 평가 방법 및 인자}

\section{1 연소실 사양 및 시험 방법}

연소 안정성을 평가할 대상 엔진은, KSR-III 로켓 개발과정에서 사용된 로켓엔진이다. 이 연 소실의 기하학적 형상과 크기는 기존의 문헌[4] 에 자세히 기술되어 있으므로 여기서는 생략한 다. KSR-III 로켓엔진으로 6회의 연소 안정성 평 가시험이 수행되었고, 그 중 4 회는 연소 안정화 기구인 배플이 장착되지 않은 상태에서 시험이 수행되었으며, 2회는 배플을 장착한 상태에서 수 행되었다. KSR-III 로켓엔진에 장착된 배플의 사 양과, 수행된 연소 안정성 평가 시험 방법 및 측 정 기법에 대한 내용은 이전의 연구[4]에 상세히 기술되어 있으므로, 여기서는 간단히 기술하겠다.

연소실의 분사기면에 배플이 장착된 형상을 Fig. 2에 나타내었다. 이전의 연구[4]에서 나타낸 


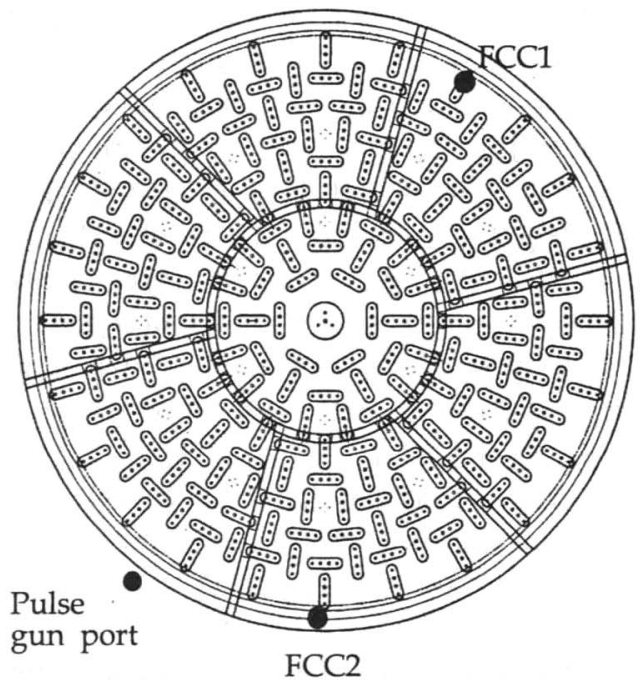

Fig. 2. Hub and six-blade baffle mounted to injector plate of unbaffled chamber (FCC1 \& 2; high-frequency pressure sensor ports)

바와 같이 배플의 블레이드와 허브의 축방향 길 이는 $90 \mathrm{~mm}$ 로 하고, 두께는 $6 \mathrm{~mm}$ 로 하였으며, 허브의 내경은 $162.8 \mathrm{~mm}$ (결과적으로 블레이드의 반경방향 길이는 $122.6 \mathrm{~mm}$ 임)이다.

연소 안정성 평가시험시 연소 구간중 설정된 순간에 인위적으로 연소실내부에 압력교란이 인 가된다. 이를 위해 압력교란 장치(artificial disturbance device)가 연소실벽에 장착된다[2, 5]. 연소 안정성 평가시험을 위한 압력교란의 목 적으로 여러 가지 교란 장치가 사용되어 왔으며, KSR-III 로켓엔진 개발 과정에서는 펄스 건(pulse gun) 장치를 사용하였다. 1 회의 시험시 다른 순 간에 두 번의 펄스를 인가할 수 있으며, 교란의 크기는 펄스 건에 충진한 폭약량을 $0.6 \sim 1.8 \mathrm{~g}$ 의 범위에서 변화시켜 조정하였다.

펄스 건에 의한 압력교란 원리는 다음과 같다. 폭약이 충진된 펄스 건을 연소실벽에 장착한 후, 원하는 시각에 폭약을 전기적으로 점화 - 폭발시 켜 발생하는 강한 압력파가 연소실내에 유입되어 연소장에 압력교란을 인가하게 된다. 펄스 압력 의 크기는, 폭약량외에 연소실내 연소조건에 따 라서도 달라진다.

펄스 건의 장착위치는 분사기면의 중심을 원 점으로 하여 $(r, \theta, z)$ 좌표계로 나타냈을 때, $\left(210 \mathrm{~mm}, 240^{\circ}, 96 \mathrm{~mm}\right)$ 이다. 연소 및 안정성 평 가시험시 발생하는 고주파의 압력 섭동을 측정하 기 위해, $25 \mathrm{kHz}$ 의 분해능(resolution or sampling rate)을 갖는 압력센서(FCC1, FCC2)가 연소실벽 에 장착되며, 그 위치는 각각 $\left(210 \mathrm{~mm}, 50^{\circ}\right.$, $96 \mathrm{~mm}),\left(210 \mathrm{~mm}, 275^{\circ}, 96 \mathrm{~mm}\right)$ 이다. Fig. 2에 펄 스 건과 고주파 압력센서의 상대위치를 표시하였 다.

\section{2 시험 조건}

로켓엔진의 작동조건을 나타내는 대표적인 인 자는 연소실 압력과 산화제/연료의 질량유량비 $(\mathrm{O} / \mathrm{F}$ 비 $)$ 이다. 본 시험에서 사용된 추진제로서 산화제는 액체산소(LOX), 연료는 케로신 (kerosene) 계열의 RP-1이며, 각 추진제가 F-O-O-F 형태의 충돌형 분사기를 통해 연소실내 로 분사된다. KSR-III 로켓 발사시 사용된 연료는 $\mathrm{JP}$ 계열의 연료였으나, 본 시험에서는 RP-1이 사 용되었다. 기준 설계조건(nominal or design condition)으로 $1.38 \mathrm{MPa}$ 의 연소실 압력과 2.34 의 $\mathrm{O} / \mathrm{F}$ 비를 선정하였다. 이러한 설계조건을 기준으 로 주위의 탈설계조건을 설정하였다.

\section{3 안정성 평가 인자}

연소 안정성을 평가하기 위해서 시험 데이터 를 여러 가지 수학적-통계적인 방법으로 처리할 수 있고, 다양한 인자들을 고려해 볼 수 있다. 오 직 거시적인 관점에 초점을 맞추어, 본 연구에서 동적 안정성 여분 또는 안정화 성능(capacity)을 파악하기 위해 사용된 인자들은 다음과 같다 $[2$, 6].

(1) 연소불안정 구간에서 섭동하는 첫번째 peak 의 크기와 안정 연소 구간의 평균진폭의 비, $A_{f / n}$

(2) 감쇠시간, $\tau_{e}$ : 진폭이 최대진폭의 $1 / \mathrm{e}$ 로 감 쇠하기까지 소요된 시간을 말하며, 시간 축에서 전방 탐색(forward search)으로 구하는 것보다 후방 탐색(backward search)으로 구하는 게 보수 적인 관점에서 더 안전하다.

(3) 싸이클 당 감쇠율(decay rate/cycle) : 감쇠시 간의 역수를 관심있는 주파수값으로 나눈 값이 다. 이 인자의 의미를 이해하기 쉽게 다음의 수 식으로 설명할 수 있다.

$$
p_{t}=p_{\max } e^{-\alpha t} \sin 2 \pi f_{0} t
$$

여기서 $p_{t}$ 는 압력 섭동의 진폭, $p_{\max }$ 는 초기 (최대) 진폭, $t$ 는 시간, $\alpha$ 는 감쇠율, $f_{0}$ 는 조사 대상 압력 진동의 주파수이다. 여기서 싸이클 당 감쇠율은 $\alpha / f_{0}$ 로 계산된다. 
위에서 첫 번째 인자의 값이 클수록 연소실에 큰 외부 교란이 가해짐을 의미하며, 연소 안정화 가 이루어지는 이 인자의 최대값이 동적 안정성 여분에 해당한다. 두 번째 인자의 값이 작을수록, 그리고 세 번째 인자의 값이 클수록 연소 안정화 성능이 우수하다. 실질적으로 두 번째와 세 번째 인자는 서로 반비례 관계에 있으므로 서로 독립 적이지는 않다.

\section{4 안정성 판단을 위한 기준(criterion)}

연소 안정성 평가 시험에서 안정성의 판단 기 준(criterion)으로는 다음의 두 가지를 고려할 수 있다.

$$
\begin{gathered}
\tau \leq\left[\tau_{\tau}\right] \\
A_{1}<A<A_{2}
\end{gathered}
$$

여기서 $\tau$ 는 진동이 감쇠되는 데 걸리는 시간 (damping time) -본 연구에서는 이를 $\tau_{e}$ 로 정 한다 -, $\left[\tau_{\tau}\right]$ 는 기준값, $A_{1}$ 은 인위적으로 가해 지는 진폭의 최저 값(연소 안정성 평가 시험으로 서 의미있는 최저값), $A$ 는 교란이 감쇠되는 경 우 측정된 진폭 신호에서의 최고 진폭, $A_{2}$ 는 연 소실 손상 방지를 위한 진폭의 상한을 나타낸다. 위 기준은 모두 압력파가 감쇠되는 경우에만 적 용가능한 것이지, 연소 불안정이 발생한 경우에 는 위 기준을 적용하는 것이 무의미하다. 또한, [ $\tau_{\tau}$ ] 과 $A_{1}, A_{2}$ 의 값은 시험전에 미리 설정할 수 있는 것이 아니라 대상 엔진에서의 많은 예비 시험을 통해 데이터베이스를 축적한 후, 제시될 수 있다. 주로 RP-1을 연료로 사용하고, 고압 고 추력의 러시아 엔진의 경우 통상 $\left[\tau_{\tau}\right]=15 \mathrm{~ms}$, $A_{1}=0.1 \mathrm{~atm}, A_{2}=10 \mathrm{~atm}$ (모든 주파수를 포함하는 전체 신호 기준)이며, 특정 엔진에 따라 조금씩 다르고, $A_{2}$ 는 주로 연소실의 구조 강도적 측면 에서 결정되는 값으로 그 설정 범위가 상당히 폭 넓다. 또한, 경험적으로, 통상 안정 연소시 계측 된 압력 섭동 진폭의 근 평균제곱값(root mean square; rms)의 수 배에 해당하는 진폭을 갖는 압력파를 감쇠시켜야 한다는 것이 요구되는데, 이를 $A_{1}$ 값 설정시 참고할 수 있다[6].

\section{KSR-III 엔진의 연소 안정화 성능}

\subsection{SRT 시험 결과}

KSR-III 로켓엔진으로 수행된 6회의 연소 안정 성 평가시험[4] 중 대표적인 4회의 시험 결과를 table 1에 나타내었다. 이 표에서 볼 수 있듯이, 시험번호 1 과 2 의 경우 펄스 건에 의해 연소실내 로 유입된 압력 섭동에 의해 큰 진폭의 압력 진 동이 발생하였고, 이러한 진동이 안정화되지 못 한 채 결국 연소 불안정이 야기되었다. 시험번호 3 의 경우에는 연소 안정화가 이루어졌으나, 초기 의 압력 진동 진폭이 너무 작아 센서에 의해 감 지되지 못했다. 즉, 이는 펄스 건에 장착된 압력 파 감쇠 장치에 의해 극히 작은 섭동이 연소실내 로 유입되었기 때문이다. 시험번호 4 의 경우는, 큰 진폭의 교란이 야기되었고, 그 교란이 안정화 되어 결국 안정한 연소가 회복된 경우이다.

\begin{tabular}{|c|c|c|c|c|c|}
\hline \multirow{2}{*}{\multicolumn{2}{|c|}{$\begin{array}{c}\text { 산화제 } \\
\text { 유량 } \\
{[\mathrm{kg} / \mathrm{s}]}\end{array}$}} & Test No. & $\begin{array}{c}\text { Test No. } \\
2\end{array}$ & $\begin{array}{c}\text { Test No. } \\
3\end{array}$ & Test No. \\
\hline & & 37.5 & 48.21 & 47.29 & 42.42 \\
\hline \multicolumn{2}{|c|}{$\begin{array}{c}\text { 연료유량 } \\
{[\mathrm{kg} / \mathrm{s}]}\end{array}$} & 17.4 & 24.25 & 24.77 & 18.33 \\
\hline \multicolumn{2}{|c|}{$\begin{array}{c}\text { 연소실 } \\
\text { 압력 } \\
\text { [MPa] }\end{array}$} & 1.27 & 1.68 & 1.57 & 1.33 \\
\hline \multicolumn{2}{|c|}{$\mathrm{O} / \mathrm{F}$ 비 } & 2.15 & 1.99 & 1.91 & 2.31 \\
\hline \multicolumn{2}{|c|}{$\begin{array}{c}\text { 폭약량 } \\
\text { [g] }\end{array}$} & $1.4,1.8$ & \begin{tabular}{|c|}
$0.6,1.0$ \\
(압력 파 \\
감쇠장 \\
치 삽입) \\
\end{tabular} & $\begin{array}{c}0.6,1.0 \\
\text { (압력 파 } \\
\text { 감쇠장치 } \\
\text { 삽입) }\end{array}$ & $1.0,1.4$ \\
\hline \multicolumn{2}{|c|}{ 배플장착여부 } & 미장착 & 미장착 & 장착 & 장착 \\
\hline \multicolumn{2}{|c|}{ 폭발시각 } & $\begin{array}{c}\text { 종료 } \\
\text { 2초전 } \\
\text { 1초전 } \\
\end{array}$ & \begin{tabular}{|c|} 
종료 \\
1 초전 \\
0.5 초전 \\
\end{tabular} & $\begin{array}{c}\text { 종료 } \\
1 \text { 초전 } \\
0.5 \text { 초전 }\end{array}$ & \begin{tabular}{|c|} 
종료 \\
0.6 초전 \\
0.3 초전 \\
\end{tabular} \\
\hline \multicolumn{2}{|c|}{$\begin{array}{c}\text { 연소시간 } \\
\text { [sec] }\end{array}$} & 8 & 8 & 4 & 4 \\
\hline \multirow{2}{*}{$\begin{array}{c}\text { 초기 } \\
\text { 압력 } \\
\text { 진폭 } \\
{[\mathrm{MPa}]}\end{array}$} & FCC1 & 1.2 & 0.6 & $\begin{array}{l}\text { 감지할 } \\
\text { 수 없음 }\end{array}$ & $\begin{array}{l}\text { 최대 } \\
\text { 진폭 } \\
0.933, \\
0.985\end{array}$ \\
\hline & $\mathrm{FCC} 2$ & 0.35 & $\begin{array}{l}\text { 감지할 } \\
\text { 수 없음 }\end{array}$ & $\begin{array}{l}\text { 감지할 } \\
\text { 수 없음 }\end{array}$ & $\begin{array}{c}\text { 최대 } \\
\text { 진폭 } \\
0.834, \\
1.346\end{array}$ \\
\hline \multicolumn{2}{|c|}{$\begin{array}{c}\text { 연소 안정성 } \\
\text { 특성 }\end{array}$} & $\begin{array}{l}\text { pulse } \\
\text { gun에 } \\
\text { 의 한 } \\
\text { 불알정 } \\
\text { 발생 }\end{array}$ & $\begin{array}{c}\text { pulse } \\
\text { gun에 } \\
\text { 의 한 } \\
\text { 불 안정 } \\
\text { 발생 }\end{array}$ & 안정 & $\begin{array}{l}\text { 큰 펄스 } \\
\text { 발생후 } \\
\text { 안정화 }\end{array}$ \\
\hline
\end{tabular}

Table 1. Results of stability rating tests 


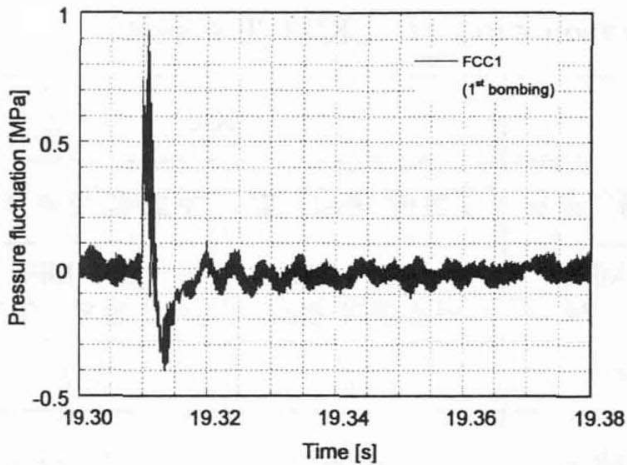

(a) without filtering

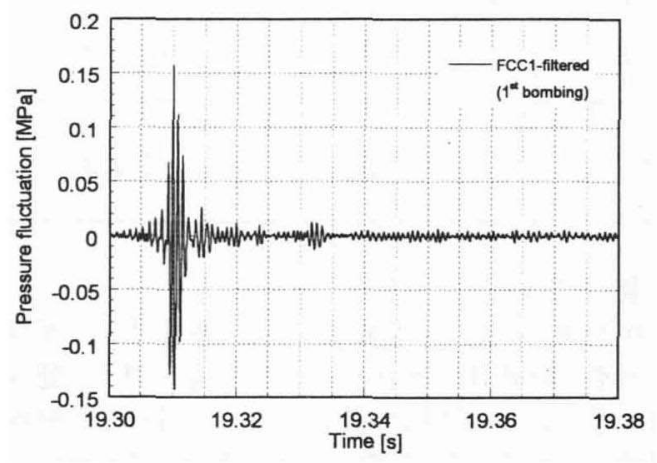

(b) with $1000 \sim 2000 \mathrm{~Hz}$ bandpass filtering

Fig. 3. High-frequency pressure fluctuation at the moment of the first bombing in test No. 4.

앞에서 언급한 연소 안정성 평가 인자들로 연 소 안정화 성능을 정량화하기 위해서는 시험번호 4 의 경우처럼 교란이 안정화되어야 한다. 총 6회 의 시험중 두 번의 시험에서만 연소 안정화를 달 성하였고, 그 중에서도 단 한번만이 연소 안정화 성능 정량화에 사용될 수 있었다. Table 1에서 '폭발시각'을 '종료 $\bigcirc \bigcirc$ 초 전'이라 표시하였는데, 여기서 '종료'라 함은 추진제 공급의 종료를 의 미하며, 통상 시험 종료(shutdown)의 의미로도 사용된다.

\section{2 연소 안정성 평가}

시험번호 4 에서 계측된 신호를 토대로 KSR-III 엔진의 연소 안정성을 평가하겠다. 두번의 폭약 폭발에 의한 교란의 크기는, $\mathrm{FCC} 1$ 상으로 각각 $0.933 \mathrm{MPa}, 0.985 \mathrm{MPa}$ 이었으며, $\mathrm{FCC} 2$ 상으로 각각 $0.834 \mathrm{MPa}, 1.346 \mathrm{MPa}$ 이었다. 이러한 값들은, 모든 주파수 값을 갖는 압력 섭동이 적분된 값들이다.

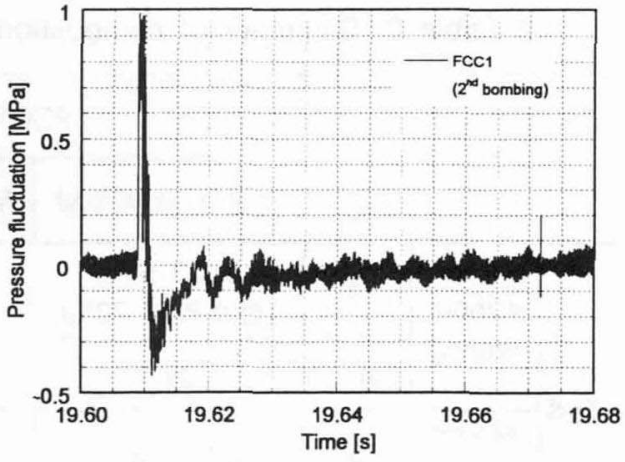

(a) without filtering

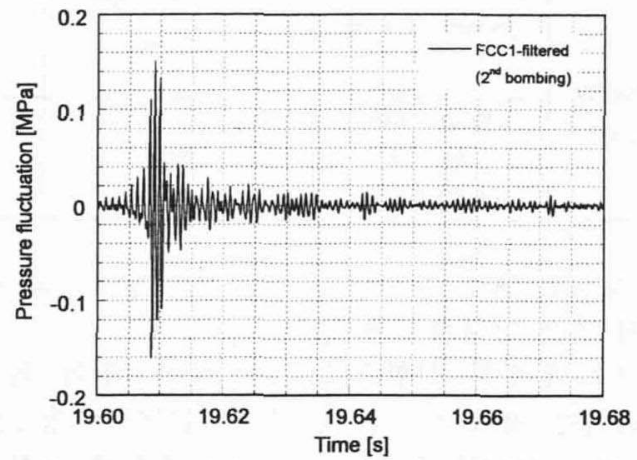

(b) with $1000 \sim 2000 \mathrm{~Hz}$ bandpass filtering

Fig. 4. High-frequency pressure fluctuation at the moment of the second bombing in test No. 4.

저주파의 압력 섭동은 고주파 연소 불안정을 야 기하는데 크게 기여하지 않으므로, 전체 신호로 부터 저주파의 효과를 배제하는 것이 바람직하 다. 여러 시험을 수행한 결과, KSR-III 엔진에서 연소 불안정 발생시 가장 유해한 주파수값은 약 $1,700 \mathrm{~Hz}$ 임을 알 수 있었다[4]. 따라서 1000 $2000 \mathrm{~Hz}$ 의 주파수 대역으로 bandpass 필터링된 신호만을 취하면, 교란의 크기는 $\mathrm{FCC} 1$ 상으로 각 각 $0.157 \mathrm{MPa}, 0.161 \mathrm{MPa}$ 이며, $\mathrm{FCC} 2$ 상으로 각각 $0.080 \mathrm{MPa}, 0.126 \mathrm{MPa}$ 이었다. 계측된 고주파 압력 섭동 신호와 필터링된 신호를 Figs. 3 4에 나타 내었다. 저주파 신호를 필터링한 데이터는 상당 히 규칙적인 압력 섭동 양상을 보이며, 전체 신 호에 비해 상대적으로 정현파적(sinusoidal) 특성 을 보이고 있다.

시험번호 4 의 시험 데이터를 토대로 연소 안정 화 성능을 나타내는 인자들을 계산하여 table 2 에 나타내었다. 2.3절과 2.4절에서 제시한 인자들 
Table 2. Summary of combustion stabilization capacity of KSR-III engine.

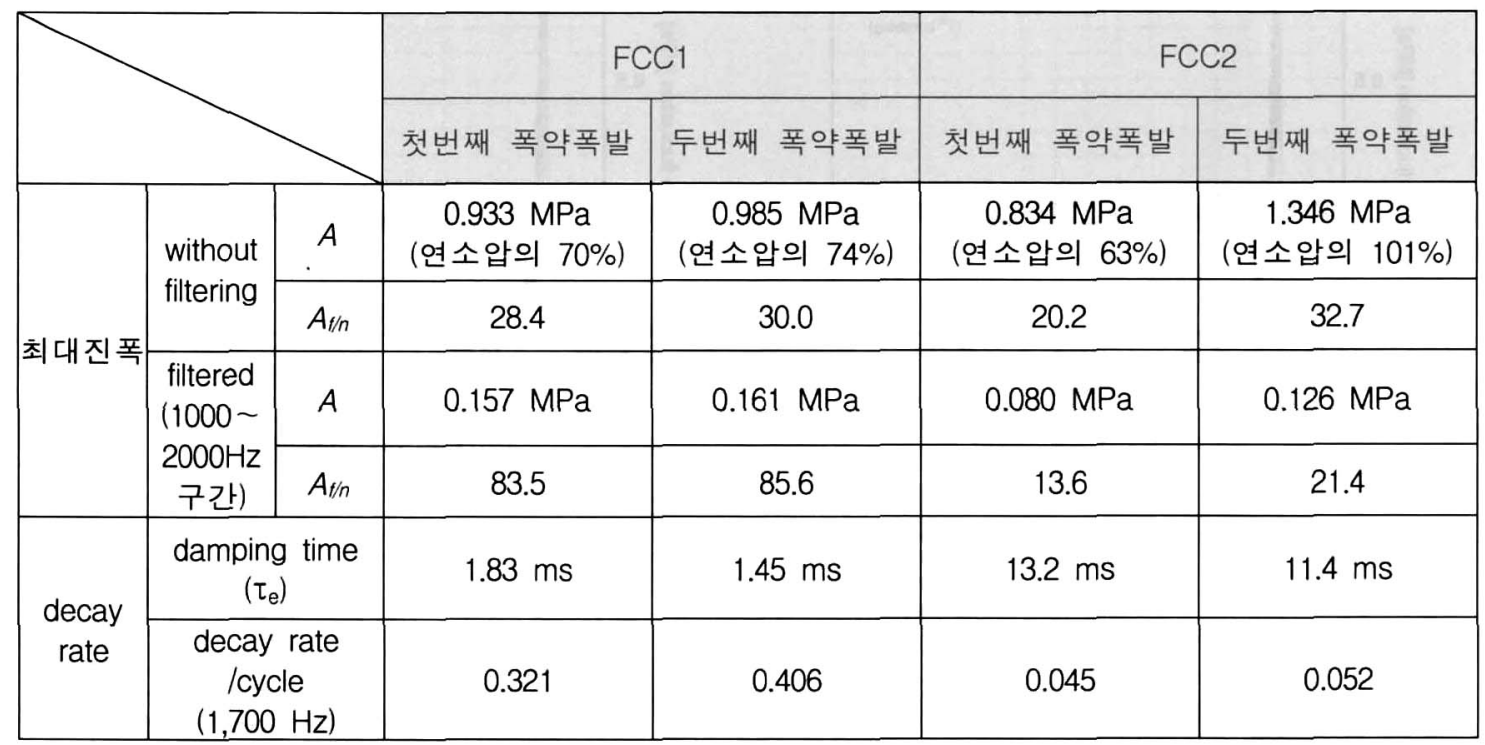

을 토대로 연소 안정성 평가 시험의 유효성과 엔 진의 연소 안정화 성능을 논의하겠다.

연소 안정성 시험으로서 유효한 시험이 되기 위해서는 앞서 언급한 $A$ 값이 의미있는 정도로 큰 값이 되어야 한다. 그 크기의 정도를 정확히 규정할 수 없기 때문에, 경험적으로 특정 크기를 받아들여야 할지의 여부를 판정할 수 밖에 없다. 본 연구에서는 결과 분석시 $A$ 와 더불어 $A_{f / n}$ 을 인자로 채택하였다. Table 2에서 보듯이, 압력 측 정 센서의 위치 및 폭발 차수에 따라 $A_{f / n}$ 이 달 라지지만, $\mathrm{O}(10)$ 의 크기에 달하므로 충분히 크기 때문에, 해당 연소 안정성 평가 시험은 유효하다 고 판정할 수 있다. 즉, 안정 연소 구간의 진폭에 비해 펄스 건에 의한 압력 섭동의 진폭이 상당히 크므로 충분히 큰 교란이 연소장에 유입되었다고 판정할 수 있다. 앞서 언급하였듯이, 1 회의 시험 을 통해 얼마나 큰 교란이 충분히 큰 교란인지에 대한 근거나 기준을 제시하기는 어렵다. 한편, 두 번째 펄스에 의해 야기된 교란의 크기가 첫 번째 펄스에 의한 것보다 크지만, 그 비율은 폭약량의 증가비율과 정확히 일치하지는 않았다.

감쇠 시간은 수 $\mathrm{ms}$ 에서 십 $\mathrm{ms}$ 정도로 상당히 짧으며, 참고로 러시아 엔진의 개발 경험을 토대 로 제시된 감쇠시간 기준값, $\left[\tau_{\tau}\right]=15 \mathrm{~ms}$ 에 비해서 짧았다. 이러한 감쇠시간을, KSR-III 엔진에서 가 장 유해했던 음향모드인 제 1 접선 방향 모드 압 력 진동의 주파수, $1,700 \mathrm{~Hz}$ 로 나누어, 한 싸이클 당 감쇠율을 계산하였고, $O(0.01 \sim 0.1)$ 의 값의 범
위를 보였다.

이상의 연소 안정화 성능을 종합하면, 배플을 장착한 KSR-III 엔진은 충분히 큰 연소 안정화 성능을 갖고 있다고 판단된다. 그러나, 정량화를 위해 활용가능한 시험이 단 1 회에 불과하여, 앞 에서 언급한 여러 정량화 인자중의 하나인 연소 안정성 여분을 찾을 수는 없었고 통계처리를 통 해 인자들의 값을 제시할 수 없었다. 그럼에도 불구하고, 안정 연소 구간의 압력 섭동 평균 진 폭에 비해 상당히 큰 인위적인 교란을 감쇠시켜 연소 안정화를 이룬 점과 상당히 짧은 시간에 연 소 안정화가 달성된 점에 근거하여 충분한 안정 화 성능을 갖춘 것으로 판정할 수 있다.

\section{IV. 결 론}

KSR-III 액체 로켓엔진 개발과정에서 수행된 연소 안정성 평가 시험을 통해, 로켓엔진의 연소 안정성을 평가하였다. 이를 위해 먼저, 연소 안정 화 성능을 정량화할 수 있는 인자를 도입·정의 하고, 이를 평가하는 방법을 검토하였다. 다음으 로, 실제 시험결과를 토대로 정량화된 인자를 구 하였다. 각 인자들이 특정의 값을 가질 때 해당 엔진이 연소 안정성을 보장할 수 있느냐의 여부 를 판정하는 것이, 연소 안정성 평가 시험 및 그 결과 분석의 궁극적인 목적이겠으나, 그러한 판 정을 내릴 수 있는, 보편화된 절대적 기준을 얻 기가 어려우며, 더구나 새로이 개발되는 엔진의 경우에는 데이터베이스가 없으므로 불가능하다. 
따라서, 차선책으로 본 연구에서 제시한 인자들 의 값은, 과거 로켓 개발 프로그램에서 경험적으 로 얻은 하나의 기준값들과 비교되었다.

성공적으로 완료된 KSR-III 엔진 개발과정에서, 로켓엔진의 안정성 확보를 위해 6회의 안정성 평 가 시험이 수행되었으며, 단 1회의 시험만이 안 정화 성능의 정량화에 활용될 수 있었다. 이를 토대로, 본 연구에서 제시한 안정화 성능의 정량 화 방법을 KSR-III 엔진에 적용하여 엔진의 안정 화 성능을 분석하였다. 그 결과, 배플을 장착한 KSR-III 엔진은, 상당히 큰 인위적인 교란에 대해 서 연소 안정화를 이룰 수 있고, 외부 교란을 상 당히 짧은 시간에 감쇠시켜 본래의 안정한 연소 를 회복할 수 있으며, 따라서 충분한 안정화 성 능을 갖춘 것으로 판정되었다. 결과적으로, 비록 연소 안정화 성능의 정량화로서 의미있는 시험은 1 회에 불과하였으나, 앞서 수행된 많은 연소 시 험의 결과와 6 회의 안정성 평가 시험을 토대로 발사전에 상당한 정도의 안정성을 확보하였음을 검증할 수 있었다. 한편, 여기서 제시한 정량화된 인자들은, 향후 수행될 유사한 시험 및 분석 과 정에서 유용한 기본 자료로 활용될 수 있을 것이 다.

본 연구를 통해 연소 안정화 성능을 나타내는 거시적 인자들이 도입되었고 정량화되었다. 로켓 엔진 연소기 시스템은 수학적으로 볼 때, '강한 비선형 시스템’이기에 다양한 비선형적 거동과 그로인한 국부적인 동적(dynamic) 양상을 보일 수 있다[7-9]. 수학적 측면에서, 연소 불안정 현상 이 내포하고 있는 비선형 거동에 대한 분석은 향 후의 연구에서 다루어질 것이다.

\section{후 기}

본 연구는 과학기술부에서 시행한 특정연구개 발사업인 "KSR-III 과학로켓 개발사업" 및 “소형 위성 발사체(KSLV-I) 개발사업"의 연구 결과 중
일부이며 이에 관계자 여러분께 감사드립니다.

\section{참고문헌}

1) Huzel, D. K. and Huang, D. H., Modern Engineering for Design of Liquid-Propellant Rocket Engines, Vol. 147, Progress in Astronautics and Aeronautics, AIAA, Washington, DC, 1992.

2) Harrje, D. J. and Reardon, F. H. (Eds.), Liquid Propellant Rocket Instability, NASA SP-194, 1972.

3) Sutton, G. P., Rocket Propulsion Elements, 6th ed., John Wiley \& Sons, Inc., New York, 1992.

4) 손채훈, 설우석, 이수용, 김영목, 이대성, "액체 로켓엔진에서 연소 안정화기구의 적용 효 과”, 한국항공우주학회지, 제31권, 제6호, 2003, pp. 79-87.

5) Agarkov, A. F. et al., "Injector Flame Stabilization Effects on Combustion Instability," in Liquid Rocket Engine Combustion Instability (V. Yang and W. E. Anderson, Eds.), Vol. 169, Progress in Astronautics and Aeronautics, AIAA, Washington, DC, 1995, pp. 281-305.

6) 김영목, 문윤완, 김성구, 손채훈, "위성발사 체 로켓엔진의 연소 불안정 억제/방지 기술," 한 국항공우주연구원 연구보고서(H02030), 2003.

7) Drazin, P. G., Nonlinear Systems, Cambridge Univ. Press, Glasgow, UK, 1992.

8) Bendat, J. S. and Piersol, A. G., Random Data Analysis and Measurement Procedures, $2^{\text {nd }}$ Ed., John Wiley \& Sons, Inc., New York, 1986.

9) Bendat, J. S., Nonlinear System Techniques and Applications, $2^{\text {nd }}$ Ed., John Wiley \& Sons, Inc., New York, 1998. 